Volume 16 Issue 1 Year: 2019

\title{
Evaluation of dietary magnesium intake and its association with depression, anxiety and eating behaviors
}

\author{
Nagihan Kırcalı Haznedar ${ }^{1}$ \\ Pelin Bilgiç ${ }^{2}$
}

\begin{abstract}
Research problem/Aim: Magnesium is an essential mineral for the organism. Magnesium which is necessary for the ability of more than three hundred enzymes to function found to be associated with many diseases. The aim of this study was to determine the intake of dietary Magnesium in university students and to define its relationship with depressive symptoms, anxiety and eating behaviors. Method: This study included 386 university students who were not diagnosed with any psychiatric disorder and were not using magnesium-containing nutritional supplements. A questionnaire of 6 sections including the general characteristics of participants like age, smoking, income status, Beck Depression Scale, Beck Anxiety Scale, 24-hour retrospective food consumption form, physical activity record form and Dutch Eating Behavior Questionnaire were applied face to face and anthropometric measurements were obtained. Statistical analyzes were performed using SPSS IBMC version 23. Findings: The average magnesium intake of participants in inadequate $\mathrm{Mg}$ intake group was 175,5 $\pm 47,6 \mathrm{mg} / \mathrm{day}$, and $353,4 \pm 107,23 \mathrm{mg} /$ day in adequate $\mathrm{Mg}$ group. Dietary Mg intake was evaluated according to Turkey Food and Nutrition Guide. It was determined that $\mathrm{Mg}$ intake of inadequate $\mathrm{Mg}$ group were met only 48,2 $\pm 12,09 \%$ of the requirement. The factors such as smoking, BMI and fiber intake were found different into groups ( $\mathrm{p}$ <0.05). It was concluded that inadequate $\mathrm{Mg}$ intake was not a risk factor for depression (OR: 1.035, 95\% CI: 0,543-1,975, $\mathrm{p}=0.916)$. Anxiety, restricting eating and emotional behaviors had no relationship with dietary $\mathrm{Mg}$ intake ( $\mathrm{p}>0.05)$, but external eating behavior scores was found to be related with $\mathrm{Mg}$ intake $(\mathrm{r}=0,110 ; \mathrm{p}<0,05)$. Conclusions: According to this research, there is no relationship between adequate $\mathrm{Mg}$ intake and depression, anxiety and eating behaviors but further research is needed.
\end{abstract}

Keywords: Magnesium; depression; anxiety; eating behaviors; nutrition.

\footnotetext{
${ }^{1}$ MSci, Hacettepe University, Health Sciences Faculty, Department of Nutrition and Dietetics, nagihankircali@,hacettepe.edu.tr.

${ }^{2} \mathrm{PhD}$. Hacettepe University, Health Sciences Faculty, Department of Nutrition and Dietetics, pbilgic@hacettepe.edu.tr. Submitted: 2019-01-02 Published: 2019-03-26
} 
Kırcalı Haznedar, N., Bilgiç, P. (2019). Evaluation of dietary magnesium intake and Its association with depression, anxiety and eating behaviors?. Journal of Human Sciences, 16(1), 345-354. doi:10.14687/jhs.v16i1.5664

\section{Introduction}

Magnesium $(\mathrm{Mg})$ is the second most abundant element in the intracellular fluid after potassium (approximately $25 \mathrm{~g}$ ), which is necessary for the ability of more than three hundred enzymes to function (Sean Strain, 2009). Mg plays an important role in electrical potential in nerve tissue and cell membranes (States, 2004). It is used as a coenzyme in carbohydrate metabolism, glucose oxidation, and oxidative phosphorylation. It is an important mineral in the provision of fluid-electrolyte balance in body fluids (Meral Aksoy, 2000).

According to the National Institutes of Health, recommended daily allowance for $\mathrm{Mg}$ is $400 \mathrm{mg}$ for females, $310 \mathrm{mg}$ for males aged-19-30 years ("National Institutes of Health Office of Dietary Supplments. Magnesium Fact Sheet for Health Professionals," 2016). Despite the physiologic role of $\mathrm{Mg}$ and its potential benefits, surveys have shown that dietary Mg intake is inadequate in Turkey as well as in other countries (King, Mainous, Geesey, \& Woolson, 2005; Sağlık Bakanlığ1 Sağlık Araştırmaları Genel Müdürlüğü, 2014). Seventy-two percent of French (Galan et al., 1997), 86\% of Americans (King et al., 2005) and 73,9\% of Turkish people have been shown to consume less than the recommended quantity (Sağlık Bakanlığ1 Sağllk Araştırmaları Genel Müdürlüğ̈̈, 2014).

The first symptoms of $\mathrm{Mg}$ deficiency are neurological and neuromuscular manifestations due to impaired potassium flow. Studies on $\mathrm{Mg}$ deficiency indicates that $\mathrm{Mg}$ may have an important role in the aetiology of mood disorders. According to the studies, one possible mechanism on the relationship between $\mathrm{Mg}$ and mood disorders is thought to be that Mg's inhibiting effect on $\mathrm{N}$-methyl D-aspartate (NMDA) receptors. $\mathrm{Mg}$ blocks glutamate entry into the cell and reduces depressive symptoms (Boyle, Lawton, \& Dye, 2017; Mlyniec et al., 2014). The other possible mechanisms are related with microbiota profile (Winther et al., 2015) and the limbic-hypothalamus-pituitary-adrenocortical axle (Hamada \& Tsuruo, 1988). Studies that aimed to investigate the relationship between dietary $\mathrm{Mg}$ intake and depressive symptoms have shown that changes in the microbiota composition affects $\mathrm{Mg}$ absorption first and then depressive behaviors (Pachikian et al., 2010; Winther et al., 2015). Several studies have showed significant results about the relationship between dietary $\mathrm{Mg}$ intake and depression. A prospective study showed that $\mathrm{Mg}$ intake, reduces risk of depression among 42-61 years old males (Yary et al., 2016). And a meta-analysis of seventeen studies concluded that there was a significant association between dietary Mg intake and depression (Li, Lv, Wang, \& Zhang, 2017). Some researchers found a significant relationship between hypomagnesemia and depression whereas others have not reached such findings (Camardese et al., 2012; Derom et al., 2012). Studies about dietary Mg intake and its relation with anxiety is limited (Jacka, Maes, Pasco, Williams, \& Berk, 2012; Sartori, Whittle, Hetzenauer, \& Singewald, 2012; Singewald, Sinner, Hetzenauer, Sartori, \& Murck, 2004). In a study, it was concluded that there was no significant association between $\mathrm{Mg}$ intake and anxiety (Jacka et al., 2012), but studies with experimental animals showed that inadequate $\mathrm{Mg}$ intake increased anxiety level (Sartori et al., 2012; Singewald et al., 2004). Therefore, data on this regard is controversial. Further studies are needed to shed on light on this issue. According to a cross sectional data from 1442 participants from the Netherlands Study of Depression and Anxiety, eating behaviors associated with dietary energy intake (Paans et al., 2019). Similarly, some researchers found that restrained eaters restrict their energy intake. External eating was found to be associated with higher levels of energy and fat intake (Anschutz, Van Strien, Van De Ven, \& Engels, 2009; Keranen, Strengell, Savolainen, \& Laitinen, 2011; Tepper, Trail, \& Shaffer, 1996). However, the data related with eating behaviors and nutrient intake generally focused on intake of macronutrients. Since there is a lack of knowledge about the relationship between eating behaviors and micronutrients, this is the first study to evaluate the association between the dietary $\mathrm{Mg}$ intake and eating behaviors.

This study was conducted to research the dietary Mg intake of college students and its relationship with depressive symptoms, anxiety and eating attitudes. Due to the limited data on this issue in Turkey, it is expected to make a significant contribution to the subject. 
Kırcalı Haznedar, N., Bilgiç, P. (2019). Evaluation of dietary magnesium intake and Its association with depression, anxiety and eating behaviors?. Journal of Human Sciences, 16(1), 345-354. doi:10.14687/ihs.v16i1.5664

\section{Method}

\subsection{Population and sample selection}

This study is a cross-sectional study carried on randomly selected-386 university students between 1 April and 30 May 2017. A signed informed consent form in accordance with Helsinki Declaration was obtained from the participants who agreed to participate in the study voluntarily. Ethical approval was obtained from the Ethics Committee of Hacettepe University, Ankara, Turkey (GO 17/229-37). Students, having a psychiatric diagnosis and using Mg containing supplements were excluded from the study.

\subsection{Data collection}

The data were collected by face-to-face interview method through the questionnaire form. An informed consent form was obtained from all participants. A total of 6 sections of the questionnaire including the general characteristics of participants, Beck Depression Scale, Beck Anxiety Scale, 24-hour dietary recall, physical activity records, and Dutch Eating Behaviour Questionnaire were applied, anthropometric measurements such as body weight, height, waist circumference were taken.

\subsubsection{Data collection tools}

\section{Beck Depression Inventory}

It is one of the most commonly used self-report instruments in clinical practice and research (Kaya, 2007). In order to measure the severity of depressive symptoms the scale developed by Beck et al. (Beck, 1961) in 1961 and validity to Turkish was performed by Hisli et al. (Hisli, 1989). The aim of the scale is not to diagnose depression but to objectively deduce the grades of depression symptoms (Hisli, 1989). The Cronbach alpha coefficient was found to be 0.74 in the validity and reliability study of the Turkish form (Hisli, 1989). A total of 21 items were rated with a 4-point Likert type. The points that can be taken range from 0 to $63(0=$ Positive statements about depression, $3=$ Negative statements about depression) (Sibel Kilınç, 2011). The cut-off point of the scale was determined as 17 points and above, indicating that the individuals receiving above this score had depression that required treatment (Hisli, 1989). The severity of depressive symptoms is interpreted as minimal between 0-9 points, mild between 10-16, moderate between 17-29, and severe between 30-63 (Kilinç, 2011).

\section{Beck Anxiety Inventory}

Beck et al. (Beck, 1988) was developed in 1988 and is used to determine the frequency of anxiety symptoms experienced by the individual. The scale validated for Turkish by Ulusoy et al. (Ulusoy, 1998) in 1998. How often participants respond to specific symptoms within the last week (from $0=$ no to $3=$ frequently) is based on scoring between $0-3$. The score obtained from the scale is accepted as minimal anxiety between $0-7$, mild anxiety at 8-15, medium anxiety between 16-25 points and severe anxiety between 26-63 points (Ümit Aydoğan, 2012). The higher is the score on the scale, the more likely it is that the anxiety of the individual is so severe (Aksoy, Özkorumak, Yayl1, Arica, 2012). It has been developed so that anxiety can be easily distinguished from depression and diagnosed. Of the twenty-one questions, 4 are related to anxiety and mood, 3 are related to specific fears, and the remaining 14 questions are about physiological symptoms that occur in anxiety disorders and panic situations. The questionnaire was determined to be valid for Turkey (Ulusoy, 1998).

\section{Dutch Eating Behavior Questionnaire}

The Dutch Eating Behaviour Questionnaire was developed in 1986 by Van Strein et al. (Tatjana van Strein, 1986). The questionnaire, consisting of 33 questions, consists of 3 subscales that assess the behavior of emotional eating, external eating, and restrictive eating. The DEBQ was answered on a 5 -point Likert scale $(1=$ never, $2=$ rarely, $3=$ sometimes, $4=$ frequent, $5=$ very often). Since there were no cut-off points for the sub-scales, the median values obtained from the study data were used as cut-off points. The Cronbach alpha coefficient was found to be 0,95 for 
Kırcalı Haznedar, N., Bilgiç, P. (2019). Evaluation of dietary magnesium intake and Its association with depression, anxiety and eating behaviors?. Journal of Human Sciences, 16(1), 345-354. doi:10.14687/ihs.v16i1.5664

restrictive eating, 0.94 for emotional eating and 0,80 for external eating (Tatjana van Strein, 1986). Translation of the scale to Turkish was made by Tekok et al. (Tekok, 1988) and the validity and reliability study in university students, by Bozan et al. (Bozan, 2009)

\section{Assessment of Dietary Magnesium Intake}

Nutrient intake was assessed by a-24-hour food recording (Gandy). The portion quantities, consumed, was determined using "Food Photograph Catalogue" (Neslişah Rakıcıoğlu, 2012), and the average intake of energy, macronutrients, and micronutrients were assessed by BEBISS (Nutrition Information System) version 8.1 (Erhardt, 2010). BEBIS is a nutrition software program that enables experts to evaluate dishes. The resulting data were evaluated according to recommended daily allowances (RDA). RDA of magnesium for healthy individuals between 19-30 years $400 \mathrm{mg} / \mathrm{d}$ for males and $310 \mathrm{mg} / \mathrm{d}$ for females according to Institute of Medicine (The Essential Guide to Nutrient Requirements, 2006).

\section{Anthropometric Measurements}

Body weight, height and waist circumference of the participants were measured by the researcher according to the validated protocols. Body mass indexes (BMI) an index based on body weight and height, were calculated by dividing weight $(\mathrm{kg})$ to the square of the height $(\mathrm{m})$ and evaluated according to the World Health Organization BMI classification (Organisation). Weight was measured wearing light clothes and no shoes using Tanita HA 622; height was measured without shoes with a stadiometer, waist circumference was measured in the middle of the iliac prominence and the lowest rib of the participant with an inflexible tape (Organisation; WHO. Report of a WHO Expert Consultation, 2008).

\subsection{Evaluation of data}

Statistical analysis was performed using SPSS IBMC version 23 (Nie NH., 1975). The sample size was obtained by calculating the minimum number of people to be reached according to $80 \%$ power level and $p=0.05$ significance level by Pass Out programme. The distribution of variables was examined by Kolmogorov-Smirnov/Shapiro-Wilk tests, descriptive statistics were expressed as mean \pm standard deviation for normally distributed numerical variables and frequency tables for identifying categorical variables. In the evaluation of categorical data, $\mathrm{x}^{2}$ and Fisher exact tests, Mann Whitney U test, Kruskal Wallis test or t-test in independent groups were used for numerical variables, Pearson correlation test was examined for normally distributed numerical values and correlation coefficients were determined by Alpar et al. (Alpar, 2016). For the multivariate analyses, the possible factors identified with univariate analyses were further entered into the logistic regression model analysis. If the variable has associated with both outcome and variable $(p<0,05)$, it was considered a potential confounder and included into the model. $\mathrm{Mg}$ is also explored as an outcome of energy intake (milligrams of Magnesium/1000 kcal). Hosmer-Lemeshow goodness of fit statistics were used to assess model fit. A 5\% type of error was used to infer statistical significance.

\section{Results}

General characteristics and anthropometrical measurements were shown according to RDA of Mg in Table 1. We evaluated 191 males and 195 females. The average age of participants was $22,2 \pm 2,42$ years. Total Mg intake was $175,5 \pm 47,6 \mathrm{mg}$ (meet the requirement $48,2 \pm 12,09 \%$ ) in

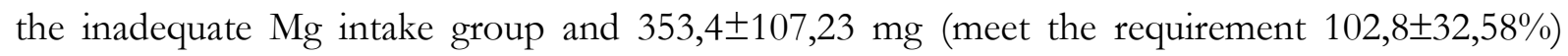
(Data is not shown) for adequate $\mathrm{Mg}$ intake group. General characteristics such as age, income status is not statistically different among groups, physical activity level was not different, either. However, it was observed that as smoking was different among the groups $(p<0,001)$, weight, BMI, waist circumference was found higher in inadequate $\mathrm{Mg}$ intake group $(\mathrm{p}<0,001)$. Daily energy and magnesium, calcium, fiber, folate intakes of participants categorized by RDA of $\mathrm{Mg}$ were given in Table 1 , also. It is showed that dietary fiber and folate intake was found higher in the adequate $\mathrm{Mg}$ intake group $(\mathrm{p}<0,001)$. 
Kırcalı Haznedar, N., Bilgiç, P. (2019). Evaluation of dietary magnesium intake and Its association with depression, anxiety and eating behaviors?. Journal of Human Sciences, 16(1), 345-354. doi:10.14687/jhs.v16i1.5664

Table 1. General characteristics, anthropometric measurements and dietary intake of some nutrients of participants according to dietary $\mathrm{Mg}$ intake.

\begin{tabular}{|c|c|c|c|c|c|}
\hline \multirow[b]{2}{*}{ Variable } & \multicolumn{3}{|c|}{ Dietary Mg intake } & \multirow[b]{2}{*}{ Overall } & \multirow[b]{2}{*}{$\mathrm{p}$} \\
\hline & & $<\mathrm{RDA}(\mathrm{n}=156)$ & $\geq \operatorname{RDA}(n=230)$ & & \\
\hline Age & & $22,2 \pm 2,54$ & $22,2 \pm 2,34$ & $22,2 \pm 2,42$ & 0,711 \\
\hline Gender ( $\%$ male $)$ & & 61,5 & 41,3 & 49,4 & 0,124 \\
\hline Low income $(\%)$ & & 14,7 & 12,6 & 13,5 & 0,224 \\
\hline \multirow[t]{3}{*}{ Smoking Status (\%) } & Non-smoker & 65,4 & 77,8 & 20,5 & 0,000 \\
\hline & Ex-smoker & 4,5 & 8,3 & 6,7 & \\
\hline & Smoker & 30,1 & 13,9 & 72,8 & \\
\hline Weight (kg) & & $69,5 \pm 14,62$ & $64,5 \pm 12,79$ & $66,6 \pm 10,65$ & 0,000 \\
\hline $\mathrm{BMI}\left(\mathrm{kg} / \mathrm{m}^{2}\right)$ & & $23,3 \pm 3,57$ & $22,1 \pm 3,30$ & $22,6 \pm 3,15$ & 0,001 \\
\hline Waist $(\mathrm{cm})$ & & $82,8 \pm 13,05$ & $78 \pm 11,35$ & $80 \pm 9,90$ & 0,000 \\
\hline Physical activity level & & $1,78 \pm 0,43$ & $1,8 \pm 0,32$ & $1,79 \pm 0,37$ & 0,644 \\
\hline Energy $(\mathrm{kcal} / \mathrm{d})$ & & $1579,8 \pm 469,71$ & $2352,5 \pm 650,45$ & $2040,9 \pm 693,55$ & 0,000 \\
\hline Dietary $\mathrm{Mg}$ intake $(\mathrm{mg} / \mathrm{d})$ & & $175,5 \pm 47,6$ & $353,4 \pm 107,23$ & $281,5 \pm 124,15$ & 0,000 \\
\hline Calcium (mg/d) & & $497,6 \pm 211,16$ & $800,2 \pm 348,98$ & $681,8 \pm 335,45$ & 0,232 \\
\hline Dietary fiber $(g / d)$ & & $14,1 \pm 5,66$ & $26,6 \pm 9,6$ & $21,5 \pm 10,15$ & 0,000 \\
\hline Folate $(\mu \mathrm{g} / \mathrm{d})$ & & $226,9 \pm 143,1$ & $411,2 \pm 201,0$ & $336,7 \pm 199,95$ & 0,001 \\
\hline
\end{tabular}

Abbreviations: BMI=Body mass index, RDA= Recommended daily allowances. Note: Data was presented percentages (\%) or mean \pm SD.

Table 2 presents depression, anxiety and eating behavior scores of participants according to RDA of Mg. Depression scores were higher in in inadequate $\mathrm{Mg}$ intake group $(\mathrm{p}=0,017)$. But, the significance disappeared after adjustments (Table 4) and there was no correlation between the variables (Table 3). Anxiety scores were higher in inadequate $\mathrm{Mg}$ intake group, too. But it was not statistically different $(\mathrm{p}=0,701)$. When looking at eating behaviors, emotional eating and external eating behaviors were higher inadequate $\mathrm{Mg}$ intake group compared to the inadequate intake group ( $\mathrm{p}=0,009, \mathrm{p}=0,008$ respectively), but there was no correlation with dietary $\mathrm{Mg}$ intake and eating behaiors (Table 3)

Table 2. Depression, anxiety and eating behaviour scores of participants according to dietary Mg intake.

\begin{tabular}{|c|c|c|c|c|}
\hline \multicolumn{5}{|c|}{ Dietary $\mathrm{Mg}$ intake } \\
\hline & $<$ RDA $(n=156)$ & $\geq \operatorname{RDA}(\mathrm{n}=230)$ & Over & \\
\hline Scores & Mean \pm SD & Mean \pm SD & Mean \pm SD & $\mathbf{P}$ \\
\hline Depression & $14,9 \pm 8,47$ & $12,9 \pm 7,17$ & $13,7 \pm 7,7$ & 0,017 \\
\hline Anxiety & $12,0 \pm 9,21$ & $11,7 \pm 9,44$ & $11,8 \pm 9,3$ & 0,701 \\
\hline Restrictive eating behavior & $2,1 \pm 0,89$ & $2,2 \pm 0,86$ & $2,2 \pm 0,87$ & 0,324 \\
\hline Emotional eating behavior & $2,1 \pm 0,97$ & $2,4 \pm 1,13$ & $2,3 \pm 1,0$ & 0,009 \\
\hline External eating behavior & $2,4 \pm 0,72$ & $2,6 \pm 0,77$ & $2,6 \pm 0,76$ & 0,008 \\
\hline
\end{tabular}


Kırcalı Haznedar, N., Bilgiç, P. (2019). Evaluation of dietary magnesium intake and Its association with depression, anxiety and eating behaviors?. Journal of Human Sciences, 16(1), 345-354. doi:10.14687/jhs.v16i1.5664

Table 3. Correlation of depression, anxiety and eating behaviour scores according to dietary magnesium intake

\begin{tabular}{|c|c|c|c|c|c|c|}
\hline \multirow[b]{3}{*}{ Parameters } & \multicolumn{4}{|c|}{ Dietary Mg intake } & & \\
\hline & \multicolumn{2}{|c|}{$<$ RDA $(\mathrm{n}=156)$} & \multicolumn{2}{|c|}{$\geq \operatorname{RDA}(n=230)$} & \multicolumn{2}{|c|}{ Overall } \\
\hline & rho & $\mathrm{P}$ & rho & $\mathrm{p}$ & rho & $\mathrm{p}$ \\
\hline Depression & 0,039 & 0,632 & 0,020 & 0,760 & $-0,730$ & 0,155 \\
\hline Anxiety & $-0,086$ & 0,284 & $-0,011$ & 0,873 & $-0,032$ & 0,525 \\
\hline Restrictive eating behavior & $-0,111$ & 0,169 & $-0,101$ & 0,126 & $-0,033$ & 0,518 \\
\hline Emotional eating behavior & $-0,115$ & 0,155 & $-0,064$ & 0,334 & 0,041 & 0,420 \\
\hline External eating behavior & $-0,013$ & 0,872 & 0,045 & 0,498 & 0,117 & 0,022 \\
\hline
\end{tabular}

Abbreviations: rho: Pearson correlation coefficient.

This data revealed that depression, emotional eating and external eating behavior was significantly different between the groups. However, after adjustments based on binary logistic regression model analysis, the difference between groups' depression scores had no longer significant (Table 4).

Table 4. Risk of depression according to RDA of $\mathrm{Mg}$ using the logistic regression model.

\begin{tabular}{lccc}
\hline & OR & $\% 95 \mathrm{Cl}$ & $\mathrm{p}$ \\
\hline Model 1 & 1,394 & $0,897-2,167$ & 0,140 \\
Model 2 & 1,248 & $0,785-1,983$ & 0,349 \\
Model 3 & 1,035 & $0,543-1,975$ & 0,916 \\
\hline
\end{tabular}

Model 1 adjusted for age

Model 2 adjusted for model 1 and smoking status, alcohol using status, BMI, physical activity level

Model 3 adjusted for model 2 and total energy intake (kcal/day), n-3 fatty acid intake (g/day), fiber intake (g/day), vitamin $\mathrm{B}_{1}, \mathrm{~B}_{6}, \mathrm{C}(\mathrm{mg} /$ day) and folate $(\mu \mathrm{g} /$ day) and iron (mg/day) intake.

\section{Discussion and Conclusions}

Magnesium is the second most abundant element in the intracellular fluid after potassium, which is necessary for the ability of more than three hundred enzymes to function (Sean Strain, 2009). Despite the physiological role of $\mathrm{Mg}$ and its potential benefits, surveys have shown that dietary Mg intake is inadequate in Turkey as well as in other countries (Galan et al., 1997; King et al., 2005; Sağlık Bakanlığı Sağlık Araştırmaları Genel Müdürlügü, 2014). This cross-sectional study was planned to assess dietary $\mathrm{Mg}$ intake and whether there was an association between dietary $\mathrm{Mg}$ intake and depression, anxiety and eating behaviors among university students. According to Turkey Food and Health Research 2010, overall dietary Mg intake was observed 272,9 $\pm 130,24$ mg/d (Sağlık Bakanlı̆̆1 Sağlık Araştırmaları Genel Müdürlüğü, 2014). In this study inadequate Mg intake group was observed to intake $175,5 \pm 47,6 \mathrm{mg} / \mathrm{d}$ and adequate $\mathrm{Mg}$ intake group was observed to intake Mg 353,4 $\pm 107,23 \mathrm{mg} / \mathrm{d}$. According to the studies (Ford \& Mokdad, 2003; Schulze et al., 2007), dietary Mg intake was lower in Turkey. This may be related to the sociocultural habits, dietary styles and the level of development. The reason for this difference is thought to comes from the genetic factors. Another factor that effecting dietary Mg intake was the level of $\mathrm{Mg}$ in the soil and growing conditions of the plants. Policies for good agricultural practices may be useful in increasing $\mathrm{Mg}$ intake.

In this study we have observed that some variables including smoking, weight, BMI, waist circumference was different between groups designed to dietary $\mathrm{Mg}$ intake. It was showed that smoking is more prevalent among the inadequate $\mathrm{Mg}$ intake group. Similar results were obtained from the studies, it was showed that non-smokers or ex-smokers had higher dietary Mg intake according to smokers (He et al., 2006; Song, Manson, Buring, \& Liu, 2004). It is thought that replacing cigarette with $\mathrm{Mg}$ rich food like almond, nut is a way of giving up cigarettes. So, smokers had reduced $\mathrm{Mg}$ intake in comparison to the others. 
Kırcalı Haznedar, N., Bilgiç, P. (2019). Evaluation of dietary magnesium intake and Its association with depression, anxiety and eating behaviors?. Journal of Human Sciences, 16(1), 345-354. doi:10.14687/jhs.v16i1.5664

It was found that the BMI and weight values of participants who had an adequate $\mathrm{Mg}$ intake were significantly lower. Similarly, a study conducted by Song et al. (Song et al., 2005) in women over 45 years reported that BMI and weight decreased as dietary $\mathrm{Mg}$ intake increased. The reason for this is thought to be the role of the $\mathrm{Mg}$ in carbohydrate metabolism and insulin secretion. Individuals may be advised that taking enough $\mathrm{Mg}$ to reduce their BMI values.

In our study, we have found no significant association between groups of $\mathrm{Mg}$ intake in depression, anxiety and eating behavior scores of students. These findings were in line with a Spanish follow-up study in university graduates (Derom et al., 2012). Derom et al, was studied among university graduates' individuals. They assessed Mg intake with a validated food frequency form, and assessed depression with self-reports. While the other methodologic aspects were similar, the assessment method of Mg intake was different between the two studies. Our samples were young and highly educated. Nevertheless, epidemiologic literature about $\mathrm{Mg}$ intake and depression was contradictory. In a study conducted by Yary et al. (Yary et al., 2016) among 2320 individuals 42-61 aged, it was reported that the individuals who consumed $\mathrm{Mg}$ in the lowest tertile had a higher risk of depression (HR: 0,53, Cl: 0,25-0,95, p=0,035). Similarly, in the Hordaland Health Study, 5780 individuals between 46-74 years were examined, Mg intake was evaluated by using a food consumption frequency form consisting of 169 foods and Hospital Anxiety and Depression Scale was used (Jacka et al., 2009). The results showed that depression was lower in the group of adequate $\mathrm{Mg}$ intake (OR: 0,86, Cl: 0,69-1,08). Mechanisms for the use of $\mathrm{Mg}$ in the treatment of depression have not been clarified yet. However, it plays a role in the glutamatergic transmission of $\mathrm{N}$-metil-D-aspartate receptors. That may be a part of the pathophysiology of depression (Mlyniec et al., 2014). In this study, it was found that there was no difference between depression scores after adjusting according to various factors (OR: 1.66, Cl: 0.83-3.29). It is thought that there may be several reasons why different results have been obtained from these studies. The fact that the study sample consisted of young individuals may have decreased the frequency of depression and $\mathrm{Mg}$ deficiency. The difference in the methodology of evaluation of $\mathrm{Mg}$ intake and depression may have affected the results. It may also be an effective factor for the participants to have a high level of education and have healthy lives.

In this study, it was determined that the individuals had anxiety in $28.8 \%$ of the individuals with inadequate $\mathrm{Mg}$ and in $27 \%$ of the adequate $\mathrm{Mg}$ intake group (data not shown). When anxiety scores were compared according to magnesium intake levels, there was no difference between magnesium intake groups among the anxiety scores $(p>0.05)$. In a systematic review including 18 studies, the effect of $\mathrm{Mg}$ on different types of anxiety was investigated. $\mathrm{Mg}$ intake on postpartum anxiety was not effective, but it has been suggested to be effective in other types (Boyle et al., 2017). The cross-sectional studies examining the relationship between diet $\mathrm{Mg}$ intake and anxiety are limited. Three hundred $\mathrm{mg} / \mathrm{day} \mathrm{Mg}$ support was given to university students and the difference between anxiety scores between placebo and intervention groups was evaluated; however, no difference was found (Gendle \& O'Hara, 2015). Hanus et al. (Hanus, Lafon, \& Mathieu, 2004) in a double-blind randomized clinical trial of Mg support were found to cure anxiety. The reason why we obtained different results from this study was thought to be this study had been a cross-sectional study and the methodology of research while evaluating anxiety.

Literature about the relationship between eating behaviors and dietary intake generally focus on dietary macronutrient intake. This is the first study in terms of examining the association between diet Mg intake and eating behaviors. Since DEBQ does not have any cut-off points, the median values obtained from the study data were used as cut-off points for each behavior. While the eating behaviors of individuals according to $\mathrm{Mg}$ intake levels were examined, there was no difference between groups' restrictive eating behavior scores; but emotional eating and external eating behavior scores were found to be different in individuals with inadequate levels of $\mathrm{Mg}(\mathrm{p}<0.05)$. Both emotional eating and external eating scores were found to be higher in adequate $\mathrm{Mg}$ group. But, the significance of emotional eating didn't last in correlation tests. 
Kırcalı Haznedar, N., Bilgiç, P. (2019). Evaluation of dietary magnesium intake and Its association with depression, anxiety and eating behaviors?. Journal of Human Sciences, 16(1), 345-354. doi:10.14687/jhs.v16i1.5664

Only external eating and dietary $\mathrm{Mg}$ intake had significant but very weak association $(\mathrm{r}=0,117$; $\mathrm{p}=0,022)$. This suggests that adequate $\mathrm{Mg}$ intake may be not the reason but the result of emotional eating and external eating. Mg-rich foods like chocolate, almond, nuts are generally desirable foods that individuals with emotional eating and external eating behaviors tend to increase the consumption of them. As a result, their dietary Mg intake may increase. (Albrecht, 2014).

This study is important in terms of evaluating the relationship between dietary $\mathrm{Mg}$ intake and mood. Since intake of psychotropic drugs and nutritional supplements would affect homeostasis, individuals with psychological support and treatment were excluded from the study. However, there were some limitations in our study. Moreover, participants may have misreported their psychiatric status because of social bias.

In conclusion, our data suggest that dietary $\mathrm{Mg}$ intake are not associated with depression, anxiety and eating behaviour scores among university students. However, our findings cannot generalise to the entire population because of our young and generally healthy sample. Dietary $\mathrm{Mg}$ intake may ameliorate depressive symptoms in already depressed patients or elderly individuals. Further prospective studies should have confirmed our findings.

\section{References}

Beck AT., Epstein N., Steer RA. (1988). An Inventory For Measuring Clinical Anxiety: Psychometric Properties. Journal of Consulting and Clinical Psychology, 56(6). doi:dx.doi.org/10.1037/0022-006X.56.6.893

Aksoy, M. (2000). Beslenme Biyokimyası (G. Hatiboğlu Ed. 3 ed.). Ankara: Hatiboğlu Yayınevi.

Aksoy, M., Özkorumak, E., Bahadır, S., Yaylı, S., \& Aksu Arıca, D. (2012). Seboreik Dermatit Hastalarında Yaşam Kalitesi, Anksiyete ve Depresyon Düzeyleri. Turkderm, 46(1), 39-43. doi:10.4274/turkderm. 83792

Albrecht, A. (2014). The Effects of Self-Esteem and Stress on Eating Behaviours in Females. The Huron University College Journal of Learning and Motivation, 52(1).

Alpar, R. (2016). Spor, Sağlık ve Eğitim Bilimlerinden Örneklerle Uygulamalı İstatistik ve GeçerlikGüvernirlik.

Anschutz, D. J., Van Strien, T., Van De Ven, M. O., \& Engels, R. C. (2009). Eating styles and energy intake in young women. Appetite, 53(1), 119-122. doi:10.1016/j.appet.2009.03.016

Beck AT., Mendelson M., Mock J., Erbaugh J. (1961). An Inventory For Measuring Depression. Archieves of General Psychiatry, 4, 561-571.

Boyle, N. B., Lawton, C., \& Dye, L. (2017). The Effects of Magnesium Supplementation on Subjective Anxiety and Stress-A Systematic Review. Nutrients, 9(5). doi:10.3390/nu9050429

Bozan, N. (2009). Hollanda Yeme Davranışı (DEBQ) Anketinin Türk Üniversite Öğrencilerinde Geçerlik ve Güvenirliğinin Sinanması. Başkent Üniversitesi Sağlık Bilimleri Enstitüsü..

Camardese, G., De Risio, L., Pizi, G., Mattioli, B., Buccelletti, F., Serrani, R. et al. (2012). Plasma magnesium levels and treatment outcome in depressed patients. Nutr Neurosci, 15(2), 78-84. doi:10.1179/1476830512y.0000000002

Derom, M. L., Martinez-Gonzalez, M. A., Sayon-Orea Mdel, C., Bes-Rastrollo, M., Beunza, J. Sanchez-Villegas, A. (2012). Magnesium intake is not related to depression risk in Spanish university graduates. J Nutr, 142(6), 1053-1059. doi:10.3945/jn.111.155572

Dietary Reference Intakes: The Essential Guide to Nutrient Requirements. (2006). Retrieved from Erhardt, J. (2010). Beslenme Bilgi Sistemi (BEBİS) (Version 8.1). Stuttgart, Almanya. Access date: 10 September 2018.

Ford, E. S., \& Mokdad, A. H. (2003). Dietary magnesium intake in a national sample of US adults. J Nutr, 133(9), 2879-2882.

Galan, P., Preziosi, P., Durlach, V., Valeix, P., Ribas, L., Bouzid, D. et al. (1997). Dietary magnesium intake in a French adult population. Magnes Res, 10(4), 321-328.

Gandy, J. Manual Dietetic Practise. Wiley Blackwell. 
Kırcalı Haznedar, N., Bilgiç, P. (2019). Evaluation of dietary magnesium intake and Its association with depression, anxiety and eating behaviors?. Journal of Human Sciences, 16(1), 345-354. doi:10.14687/jhs.v16i1.5664

Gendle, M. H., \& O'Hara, K. P. (2015). Oral Magnesium Supplementation and Test Anxiety in University Undergraduates. Journal of Articles in Support of the Null Hypothesis, 11(2).

Hamada, H., \& Tsuruo, T. (1988). Characterization of the ATPase activity of the Mr 170,000 to 180,000 membrane glycoprotein (P-glycoprotein) associated with multidrug resistance in K562/ADM cells. Cancer Res, 48(17), 4926-4932.

Hanus, M., Lafon, J., \& Mathieu, M. (2004). Double-blind, randomised, placebo-controlled study to evaluate the efficacy and safety of a fixed combination containing two plant extracts (Crataegus oxyacantha and Eschscholtzia californica) and magnesium in mild-to-moderate anxiety disorders. Current Medical Research and Opinion, 20(1), 63-71. doi:10.1185/030079903125002603

He K., Liu K., Daviglus M. L., Morris S. J., Loria CM., Horn V. et al(2006). Magnesium intake and incidence of metabolic syndrome among young adults. Circulation, 113(13), 1675-1682. doi:10.1161/circulationaha.105.588327

Hisli, N. (1989). Beck Depresyon Envanterinin üniversite öğrencileri için geçerliği, güvenirliği. Psikoloji dergisi, 7(23), 3-13.

Jacka F. Maes N., Pasco M., Williams L., Berk, M. (2012). Nutrient intakes and the common mental disorders in women. J Affect Disord, 141(1), 79-85. doi:10.1016/j.jad.2012.02.018

Jacka F., Overland, S., Stewart, R., Tell G. S., Bjelland, I.,Mykletun, A. (2009). Association between magnesium intake and depression and anxiety in community-dwelling adults: the Hordaland Health Study. Aust N Z J Psychiatry, 43(1), 45-52. doi:10.1080/00048670802534408

Keranen AM., Strengell K., Savolainen MJ., Laitinen JH. (2011). Effect of weight loss intervention on the association between eating behaviour measured by TFEQ-18 and dietary intake in adults. Appetite, 56(1), 156-162. doi:10.1016/j.appet.2010.10.004

King DE., Mainous AG., Geesey ME., Woolson RF. (2005). Dietary magnesium and C-reactive protein levels. J Am Coll Nutr, 24(3), 166-171.

Li B., Lv J., Wang W., Zhang D. (2017). Dietary magnesium and calcium intake and risk of depression in the general population: A meta-analysis. Aust N Z J Psychiatry, 51(3), 219-229. doi:10.1177/0004867416676895

Kaya M., Kaya B., Pehlivan E.. (2007). Tip Fakültesi ve Sağllk Yüksekokulu Öğrencilerinde Depresif Belirti Yaygınlığı, Stresle Başa Çıkma Tarzları ve Etkileyen Faktörler. Türk Psikiyatri Dergisi, 18(2), 137-146.

Mlyniec K., Davies CL., de Aguero Sanchez IG., Pytka K., Budziszewska B., Nowak, G. (2014). Essential elements in depression and anxiety. Part I. Pharmacol Rep, 66(4), 534-544. doi:10.1016/j.pharep.2014.03.001

Ulusoy M., Erkmen H. (1998). Turkish Version of the Beck Anxiety Inventory: Psychometric Properties. Journal of Cognitive Psychotherapy: An International Quarterly, 12(2), 163-172.

National Institutes of Health Office of Dietary Supplments. Magnesium Fact Sheet for Health Professionals. (2016, 11.02.2016). Retrieved from https://ods.od.nih.gov/factsheets/Magnesium-HealthProfessional/\#h3. Access date:12 September 2018.

Rakıcıoğlu N., Ayaz A., Pekcan G. (2012). Yemek ve Besin Fotoğraf Kataloğu (3 ed.). Ata Ofset Matbaacilik.

Nie NH., H. C., Jenkins JG., Steinbrenner K., Bent H., . (1975). Spss Statistical Package for the Social Sciences, Second Edition. New York: McGraw-Hill Book Co., 1975. Journal of Advertising, 5(1), 41-42. doi:10.1080/00913367.1976.10672624

World Health Organisation, Body Mass Index-BMI. Retrieved from http://www.euro.who.int/en/health-topics/disease-prevention/nutrition/a-healthylifestyle/body-mass-index-bmi. Access date: 12 Semtember 2018.

Paans, N. P. G., Gibson-Smith, D., Bot, M., van Strien, T., Brouwer, I. A., Visser, M., \& Penninx, B. W. J. H. (2019). Depression and eating styles are independently associated with dietary intake. Appetite, 134, 103-110. doi:https://doi.org/10.1016/j.appet.2018.12.030 
Kırcalı Haznedar, N., Bilgiç, P. (2019). Evaluation of dietary magnesium intake and Its association with depression, anxiety and eating behaviors?. Journal of Human Sciences, 16(1), 345-354. doi:10.14687/jhs.v16i1.5664

Pachikian BD., Neyrinck AM., Deldicque L., De Backer FC., Catry E., Dewulf, E. M. et al. (2010). Changes in intestinal bifidobacteria levels are associated with the inflammatory response in magnesium-deficient mice. J Nutr, 140(3), 509-514. doi:10.3945/jn.109.117374

Sağlık Bakanlığı Sağlık Araştırmaları Genel Müdürlüğü, (2014). Türkiye Beslenme ve Sağlık Araştırması 2010. Retrieved from http://www.sagem.gov.tr/TBSA_Beslenme_Yayini.pdf. Access date: 15 September 2018.

Sartori SB., Whittle N., Hetzenauer A., Singewald, N. (2012). Magnesium deficiency induces anxiety and HPA axis dysregulation: Modulation by therapeutic drug treatment. Neuropharmacology, 62(1), 304-312. doi:https://doi.org/10.1016/j.neuropharm.2011.07.027

Schulze MB., Heidemann C., Schienkiewitz A., Hoffmann K., Boeing H. (2007). Fiber and magnesium intake and incidence of type 2 diabetes: a prospective study and meta-analysis. Arch Intern Med, 167(9), 956-965. doi:10.1001/archinte.167.9.956

Strain S. (2009). Minerals and Trace Elements. Wiley Blackwell.

Kıllıç S. (2011). Türkiye'de Klinikte Kullanılan Depresyon Degerlendirme Ölçekleri. Dirim Tip Gazetesi, 86(1), 39-47.

Singewald N, Sinner C., Hetzenauer A., Sartori S. B., Murck, H. (2004). Magnesium-deficient diet alters depression- and anxiety-related behavior in mice--influence of desipramine and Hypericum perforatum extract. Neuropharmacology, 47(8), 1189-1197. doi:10.1016/j.neuropharm.2004.08.010

Song Y., Manson JE., Buring, J. E., Liu S. (2004). Dietary magnesium intake in relation to plasma insulin levels and risk of type 2 diabetes in women. Diabetes Care, 27(1), 59-65.

Song Y., Manson JE., Cook NR., Albert CM., Buring JE., \& Liu, S. (2005). Dietary magnesium intake and risk of cardiovascular disease among women. Am J Cardiol, 96(8), 1135-1141. doi:10.1016/j.amjcard.2005.06.045

WHO, FAO.(2004). Vitamin and mineral requirements in human nutrition (pp. 217- 226). Retrieved from: https://www.who.int/nutrition/publications/micronutrients/9241546123/en/. Access date: 20 November 2018.

Van Strein T., Bergers G., Defares P. (1986). The Dutch Eating Behaviour Questionnaire (DEBQ) for Assesment of Restrained, Emotional, and External Eating Behaviour. International Journal of Eating Disorders, 5(2), 295-315.

Tekok AK. (1988). An Analysis of the Dutch Eating Behaviour Questionnaire and Its Correlation with Neurotic Personality Traits. Psikoloji. ODTÜ.

Tepper B J., Trail AC., Shaffer SE. (1996). Diet and physical activity in restrained eaters. Appetite, 27(1), 51-64. doi:10.1006/appe.1996.0033

Aydoğan Ü., Akbulut H., Tas G., Aydoğdu A., Sağlam K.. (2012). Hipertansiyon Hastalarında Anksiyete Bozukluğu. Konuralp Tip Dergisi, 4(2), 1-5.

WHO. Report of a WHO Expert Consultation. (2008). Retrieved from Geneva: http://apps.who.int/iris/bitstream/10665/44583/1/9789241501491_eng.pdf?ua=1. Access date: 15 December 2018.

Winther G., Jørgensen P., Elfving B., Nielsen DS., Kihl P., Lund S., et al. (2015). Dietary magnesium deficiency alters gut microbiota and leads to depressive-like behaviour. Acta Neuropsychiatrica, 27(3), 168-176. doi:10.1017/neu.2015.7

Yary T., Lehto SM., Tolmunen T., Tuomainen TP., Kauhanen J., Voutilainen S., et al. (2016). Dietary magnesium intake and the incidence of depression: A 20-year follow-up study. J Affect Disord, 193, 94-98. doi:10.1016/j.jad.2015.12.056 